\title{
주차공간의 차량종류별 연소특성 $\mathrm{DB}$ 구축을 위한 실험적 연구
}

\section{A Study on the Experimental to Establish Combustion Properties DB Accordance to Vehicle Model Categorizes at Parking Space}

\author{
강승구* - 김동은* - 서동구* - 김동준** - 김정희*** - 권영진**** \\ Kang, Seung Goo*, Kim, Dong Eun*, Seo, Dong Goo*, Kim, Dong Jun**, \\ Kim, Jeong-Hee***, Kwon, Young Jin****
}

\begin{abstract}
Car combustion experiment was conducted by selecting 3 cars, medium sedan, large sedan and van, for modeling of heat release rate(HRR) on car fire at parking space. Lists of measurement are internal and external temperature, HRR, mass decrement, and according to the result of experiment, it is considered that it requires review of fire resisting capacity of structure by temperature characteristic of internal and external temperature, and location of parking space structure. as a result review of fire resistance is needed. Also, Total HRR, burning speed, and heat of combustion of car were secured, and modeling of HRR for each car classification was written by using HRR. As a result, error range of total calorific value between experimental value and model value was within $10 \%$, and it proposed combustion characteristic DB by car classification for fire resistance design of parking space structure.
\end{abstract}

Key words : Vehicle combustibles test, Vehicle fire modeling, Combustion properties

\section{요지}

주차공간 차량화재에 대한 열방출율의 모델화를 위해 중형승용차, 대형승용차, 승합차 3 대의 차량을 선정하여 차량연소실험을 실시하 였으며, 측정항목은 차량의 내외부온도, 열방출량, 질량감소량이다. 온도측정결과, 내화성능평가로서 적용되는 ISO 834곡선에 비해 높 게 측정됨으로서, 내화성능의 검토가 필요할 것으로 사료된다. 또한, 차량의 총 발열량, 연소속도, 연소열 등 을 확보하였으며, 열방출 율을 이용하여 차량별 열방출율의 모델화를 작성하였다. 그 결과 실험값과 모델값의 총 발열량의 오차범위는 $10 \%$ 내에 있었으며, 주차 공간 구조물의 내화설계를 위한 차량종류별 연소특성 $\mathrm{DB}$ 를 제시하였다.

핵심용어 : 차량연소실험, 차량화재 모델링, 차량연소특성

\section{1. 서 론}

최근 사회의 급격한 발전으로 차량은 현대사회에서 필수품 으로 거듭되었다. 이러한 차량은 2012년 1,887 만대가 등록되 어있으며(통계청 2012), 주차공간은 2011년 123만 개소가 등 록되어 있다(국가교통DB센터 2012). 이러한 차량등록수와 주차공간개소는 8 년간 각각 약 $3 \%, 7 \%$ 씩 지속적으로 증가하
고 있는 추세이다.

하지만, 특수가연물로 취급되는 차량에서 화재발생시 주차 공간내 좁은 이격거리의 공간 특성과 높은 열방출율(Heat Release Rate)로 인해 화재확대가 빠르다. 또한 다량의 유독가 스발생, 초기화재 이후 화재진압의 어려움과 더불어 최근 차 량의 경량화(플라스틱 및 알루미늄 등) 및 다양화(대형화)로 인해 주차공간내 차량화재에 대한 위험성이 대두되고 있는

*정회원. 호서대학교 소방방재학과 석 · 박사과정(E-mail: skywinka@nate.com)

Member. Graduate Student, Fire Protection, Univ. of Hoseo

**정회원. 세한대학교 소방행정학과 교수

Member. Ph.D. Professor, Dept. of Fire Protection Eng, School of Eng, Univ. of Sehan

****정회원. PNR시스템 기술이사

Member. Ph.D. Director of technique. PNR System Co. 1td.

****교신저자. 정회원. 호서대학교 소방방재학과 교수(Tel: +82-41-540-5497, Fax: +82-41-540-5738, E-mail: jungangman@naver.com)

Corresponding Author. Member. Ph.D. Professor, Dept. of Fire Protection Eng, School of Eng, Univ. of Hoseo 
실정이다.

이에 따라, 국외에서는 1990 년대부터 주차공간의 차량화재 에 대한 위험성을 인지하고 실물 차량연소실험을 기반으로 한 열방출율, 화재전파 등에 대한 실험적인 연구가 진행되었 다(Shipp et al., 1995; Mangs et al., 1994; Masuda et al., 2005). 또한, 일본건축학회에서는 일반건축물의 내화설계를 위해 가연물에 대한 연소실험을 실시하였으며, 열방출율을 유 형화 및 설계용으로 모델화하였다(AIJ, 2005). 한편, 국내의 경우 2010년대부터 기초적인 차량연소실험을 실시하였으며 (유용호 등, 2010; 김동준, 2013; 김영탁, 2010), 열방출율, 내 외부 온도 등 기초적인 Data 확보에 의한 연구가 진행되었다. 그러나, 국내 차량연소 Data가 부족하고, 차량연소특성에 대 한 설계용 모델화가 구축되어 있지 않은 실정이다.

따라서 본 연구는 주차공간 구조물의 차량화재에 대한 열방 출율의 모델화를 위하여 2013년도 통계청에서 조사된 국내 승용차에서 가장 많은 비중을 차지하고 있는 중형승용차 $(56.8 \%)$, 대형승용차 $(25.1 \%)$ 와 승합차의 차량 3 대를 선정하 여 차량연소실험을 실시하였으며, 연소시 측정된 열방출율을 이용하여 차량별 열방출율을 유형화와 기초적 설계용 모델화 를 제시하였다. 또한, 연소실험시 차량의 내·외부온도를 측정 하여 차량화재시 주차공간에 미치는 영향을 확인하였고, 차량 연소특성 Data 확보를 통하여 국내 차량화재의 DB구축을 위 한 기초적 자료로 활용하고자 한다.

\section{2. 차량 종류별 연소실험 개요}

차량연소 실험은 한국건설기술연구원의 $10 \mathrm{MW}$ 급 Large Scale Calorimeter를 이용하여 연소실험을 실시하였다. 연소 실험에 사용된 차량은 다음 Table 1에 나타낸바와 같이 중형 승용차(2000cc이상 $3000 \mathrm{cc}$ 미만), 대형승용차(3000 cc 이상), 승합차 총 3 대이다. 연소실험시 조건은 폭발의 위험성으로 인 해 연료와 타이어의 공기압을 전부 제거하였다. 또한, 차량의 창문을 $30 \%$ 개방하였으며, 착화원은 헵탄 $50 \mathrm{ml}$ 을 이용하여 차량 뒷좌석 시트에 점화하여 연소실험을 실시하였다.

측정 항목은 차량화재성상과 주차공간 구조물의 화재피해 영향을 확인하기 위해 아파트 및 판매시설의 주차장조사를 통하여 Figs. 1 3과 같이 차량 내 외부(기둥, 벽) 위치에 KType 열전대를 각각 설치하였다. 또한 차량연소특성 분석을 위해 연소 전 · 후의 차량중량과 열방출율을 측정하였다.

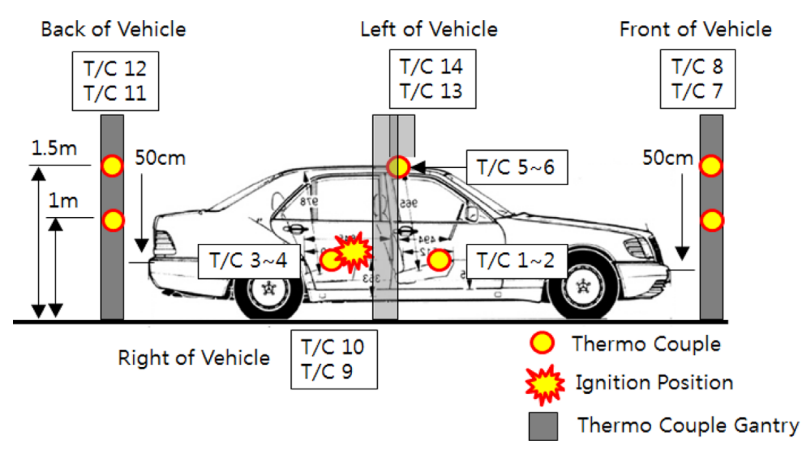

Fig. 1. Thermocouple Position (Mid-size Car).

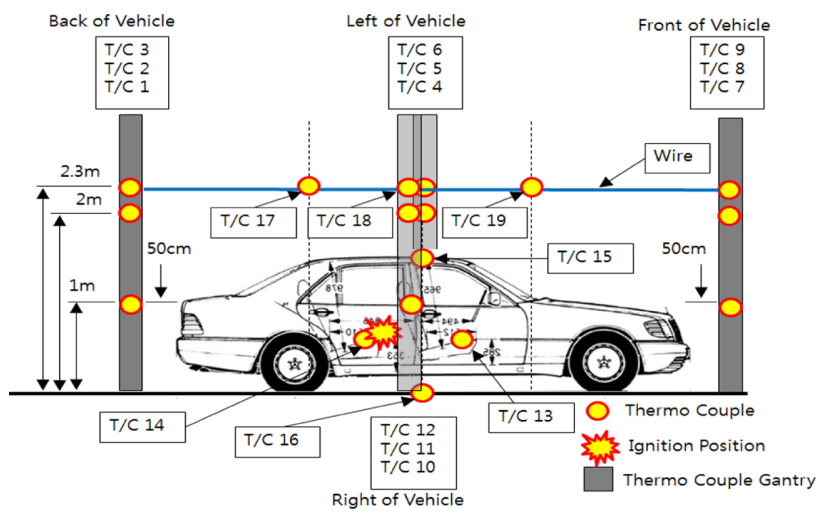

Fig. 2. Thermocouple Position (Large-size Car).

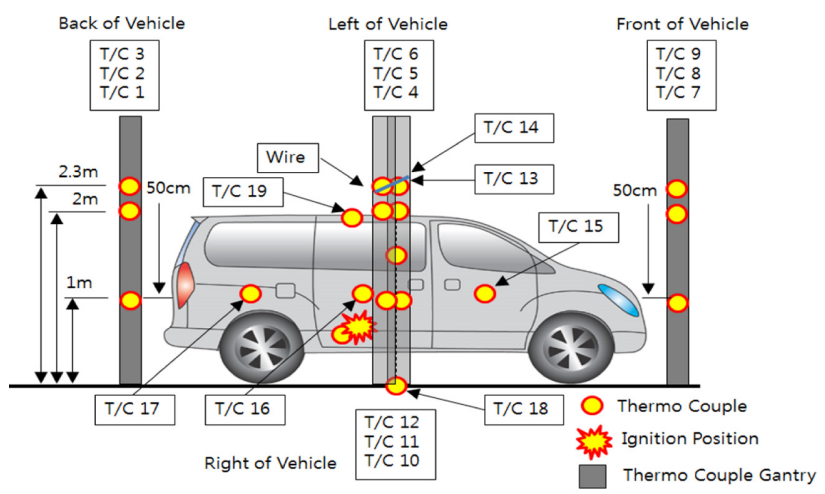

Fig. 3. Thermocouple Position (Van).

\section{3. 차량 종류별 연소실험 결과 및 분석}

\section{1 차량 연소시 온도 특성}

차량의 내 · 외부의 온도결과 그래프를 다음 Figs. 4 10에

Table 1. Experimental Specimens Conditions

\begin{tabular}{c|c|c|c|c|c}
\hline Specimens & Size $(\mathrm{W} \times \mathrm{D} \times \mathrm{H})[\mathrm{mm}]$ & Displacement $[\mathrm{cc}]$ & Weight $[\mathrm{kg}]$ & Fuel & Seating capacity \\
\hline Mid-size car & $4,700 \times 1,770 \times 1,405$ & 1,997 & 1,320 & Gasoline & 5 \\
\hline Large-size car & $4,980 \times 1,810 \times 1,445$ & 3,496 & 1,760 & Gasoline & 5 \\
\hline Van & $4,695 \times 1,840 \times 2,080$ & 2,476 & 1,916 & Diesel & 9 \\
\hline
\end{tabular}




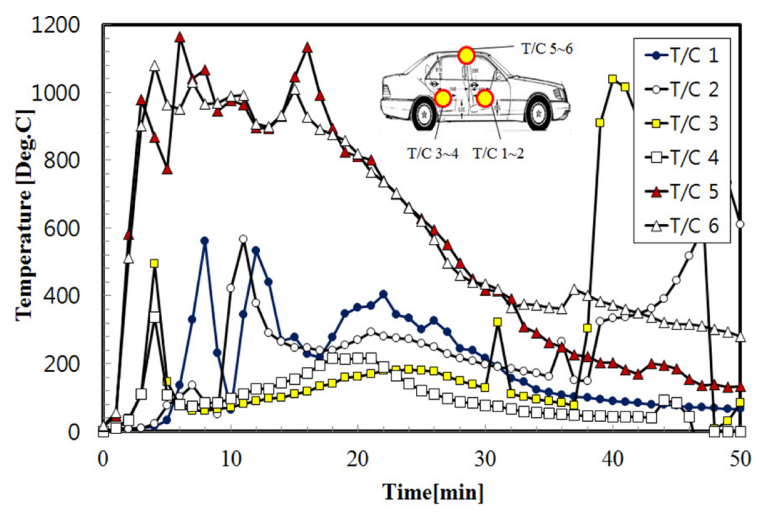

Fig. 4. Inside Temperature (Mid-size car).

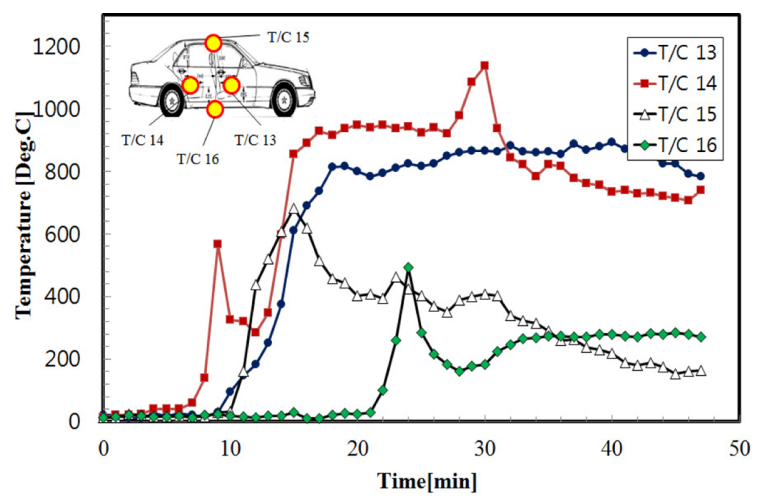

Fig. 5. Inside Temperature (Large-size car).

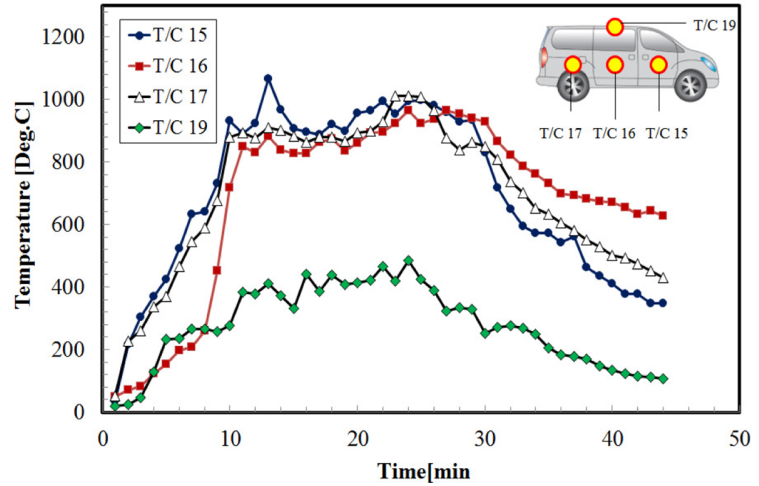

Fig. 6. Inside Temperature (Van)

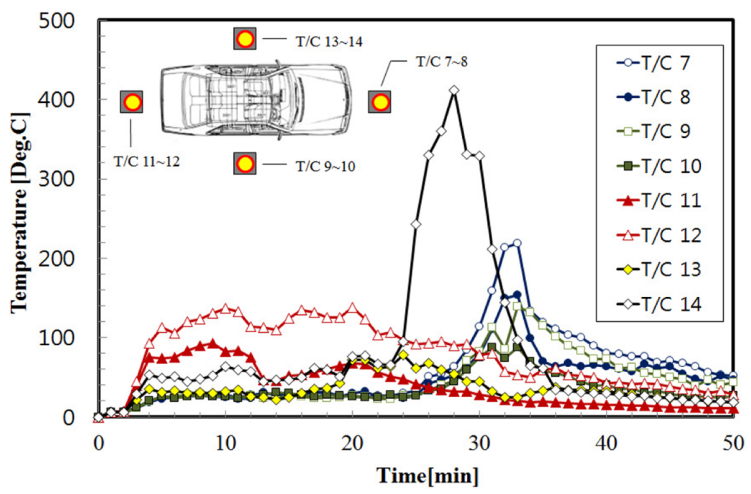

Fig. 7. Outside Temperature (Mid-size car).

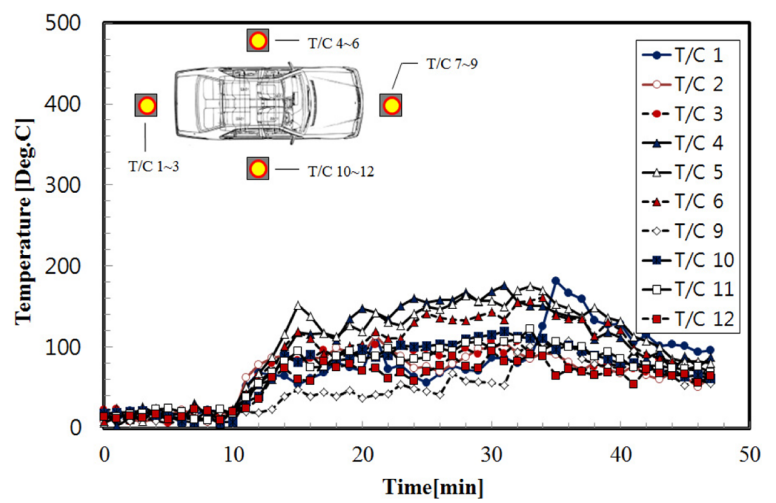

Fig. 8. Outside Temperature (Large-size car).

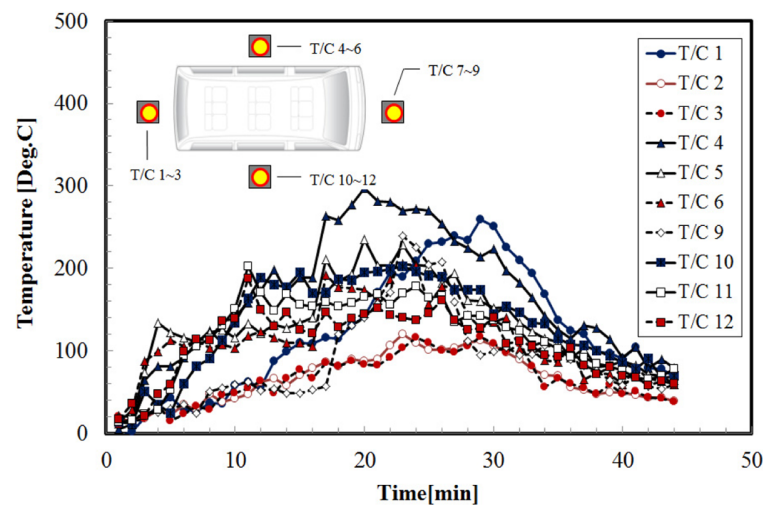

Fig. 9. Outside temperature (Van).

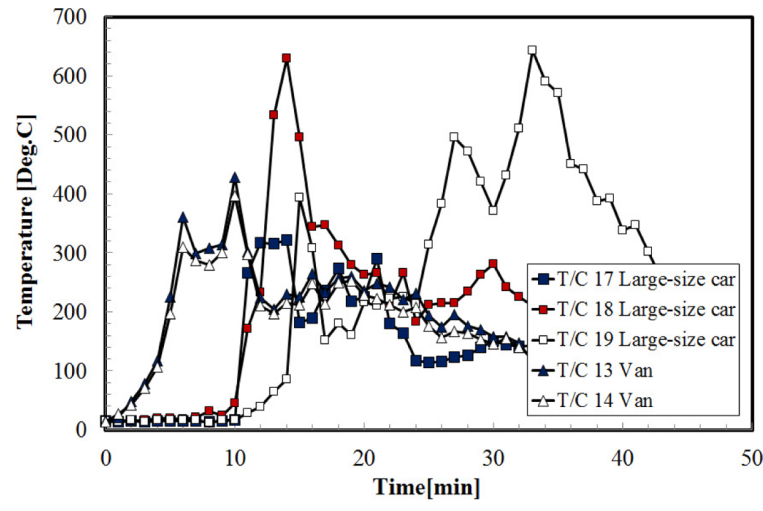

Fig. 10. Outside temperature $2.3 \mathrm{~m}$ (Large-size car and Van).

나타내었으며, 내외부의 각 지점에 대한 최고온도 값을 다음 Table 2에 나타내었다. 온도특성결과는 3종류의 차량 전체에 서 점화후 10 분 이내에 화재가 급격히 성장하는 것을 확인 할 수 있었다. 또한 부분적으로 온도가 측정되지 않은 부분이 있 지만, 전체 차량에서 최고온도는 차량의 내부에서 $1000^{\circ} \mathrm{C}$ 이 상의 고온이 측정되었다.

특히, 차량의 인접온도(보 · 기둥)는 약 $200^{\circ} \mathrm{C}$ 이내의 온도 가 확인되었지만, 차량의 상부(슬래브) $2.3 \mathrm{~m}$ 위치에서의 최 고온도는 대형승용차 $642^{\circ} \mathrm{C}$, 승합차 $428^{\circ} \mathrm{C}$ 가 측정되어 구조 물의 내화성능 검토가 필요할 것으로 판단된다. 
Table 2. Temperature Measurement Result

\begin{tabular}{c|c|c|c|c|c|c|c|c}
\hline \multirow{2}{*}{ Specimens } & \multicolumn{3}{|c|}{$\begin{array}{c}\text { Maximum temperature } \\
\left.\text { of inside [ }{ }^{\circ} \mathrm{C}\right]\end{array}$} & \multicolumn{5}{c}{$\begin{array}{c}\text { Maximum temperature } \\
\left.\text { of outside [ }{ }^{\circ} \mathrm{C}\right]\end{array}$} \\
\hline Specimens & Seat & Floor & Ceiling & Back & Left & Front & Right & $2.3 \mathrm{~m}$ \\
\hline Mid-size car & 1036.6 & - & 1164.1 & 137.7 & 411.4 & 218.5 & 139 & - \\
\hline Large-size car & 1137.7 & 492.7 & 681.5 & 181.3 & 176.5 & 107.9 & 122.1 & 642.3 \\
\hline Van & 1064.7 & - & 485.3 & 259.1 & 297.4 & 238.8 & 202.5 & 428.2 \\
\hline
\end{tabular}

\section{2 차량 연소시 열방출율 특성}

열방출율을 측정하기 위해 기초실험을 실시하여 측정장비 의 신뢰성을 확인하였다. 기초 실험은 Pool Fire 연소실험으 로 실시하였으며 연료는 헵탄(Heptane) $10 \mathrm{~L}$ 로 설정하였다. 열방출율은 장비의 산소소비법을 이용하여 측정되며, 헵탄의 총 발열량은 다음 식 (1)을 이용하여 도출할 수 있다.

실험 결과 착화후 122 초부터 계측이 되었으며, 최대 열방출 율 $1733 \mathrm{~kW}$, 총 발열량은 $350 \mathrm{MJ}$ 로 계산되었다. 이에 대한 실험계산값 $(350 \mathrm{MJ})$ 과 이론계산값 $(363 \mathrm{MJ})$ 을 비교하면 $3.7 \%$ 의 작은 값의 차가 나타나며 장비의 유효성을 확인하였다.

$$
T H R=V \times q
$$

THR: Total Heat Release [MJ]

$V$ : Heptane Volume [L] [10 L]

$\rho$ : Heptane Density $\left[\mathrm{kg} / \mathrm{m}^{3}\right]\left[0.68 \mathrm{~kg} / \mathrm{m}^{3}\right]$

$q$ : Heating Value $[\mathrm{KJ} / \mathrm{kg}][48.58 \mathrm{KJ} / \mathrm{kg}]$

차량연소실험 후 열방출율과 총 발열량을 다음 Figs. 11 14 에 나타내었으며, 각각의 연소차량 데이터에 전술한 122 초의 Delay Time을 적용하였다. 실험결과 중형승용차, 대형승용차, 승합차에서 최대 열방출율은 각각 $3.6 \mathrm{MW}, 3.6 \mathrm{MW}, 4.3 \mathrm{MW}$ 로 나타났으며, 각 차량에서 $3.6 \mathrm{MW}$ 이상의 높은 열방출율이 측정되었다. 한편, 총 발열량은 $5,253 \mathrm{MJ}, 4,789 \mathrm{MJ}, 5,860 \mathrm{MJ}$ 로 나타났다.

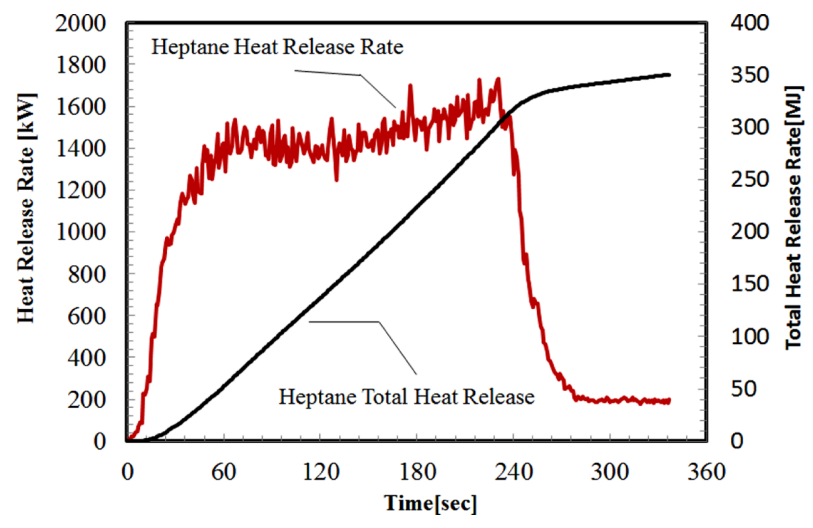

Fig. 11. HRR and THR (Heptane).

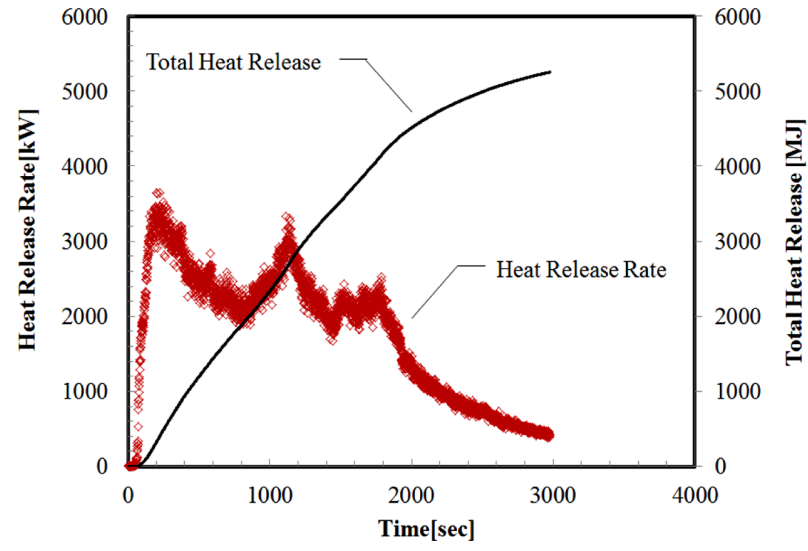

Fig. 12. HRR and THR (Mid-size Car).

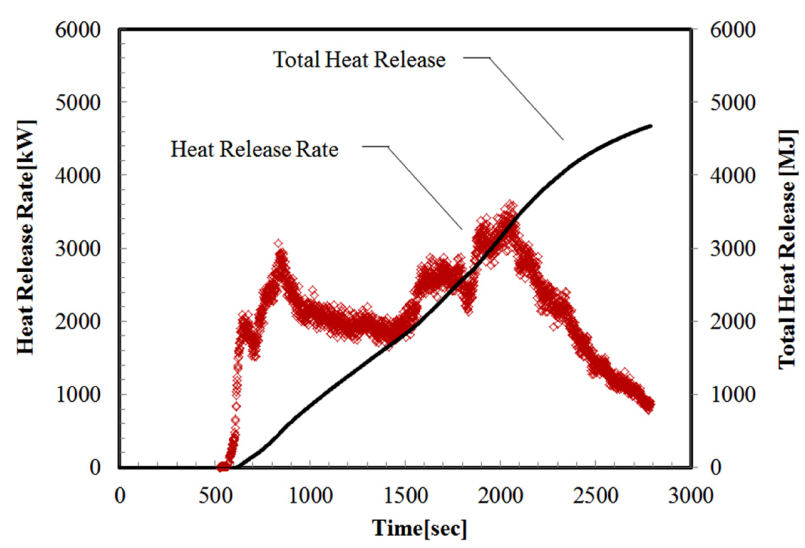

Fig. 13. HRR and THR (Large-size Car).



Fig. 14. HRR and THR (Van). 


\section{3 차량 연소 실험 결과 분석}

차량 종류별 연소실험에 대한 연소특성은 화원으로부터 착 화이후 10 분이내 차량의 유리창이 파손되는 것을 확인할 수 있었다. 또한, 유리창의 파손과 함께 산소의 유입으로 화재가 급격히 상승함에 따라 화재가 확대되는 것을 확인할 수 있었 다.

특히, 주차공간에서 차량화재 확대와 밀접한 관계인 연소속 도(Burning Rate)는 인접차량의 화재전파에 있어서 중요요소 이다. 연소속도를 산정하기 위해 차량 연소 전 - 후의 중량과 화재가 지속된 시간을 설정하여 다음 식 (2)와 같이 도출할 수 있다.

$$
B_{R}=\frac{M_{L}}{F_{D}} \times 100
$$

$B_{R}$ : Burning Rate $[\mathrm{kg} / \mathrm{min}]$

$M_{L}:$ Mass Loss $[\mathrm{kg}]$

$F_{D}$ : Fire Duration [min]

또한, 연소전 · 후의 중량을 통해 연소물비율(Combustion Ratio)의 도출도 가능하다. 이를 수식화하면 다음 식 (3)과 같 이 나타낼 수 있다.

$$
C_{R}=\frac{D_{W}}{G_{W}} \times 100
$$

$C_{R}$ : Combustion Ratio [\%]

$M_{L}$ : Mass Loss $[\mathrm{kg}]$

$T_{M}:$ Total Mass $[\mathrm{kg}]$

이에 대한 식 (2)와 식 (3)을 차량연소결과에 응용하면 다음 Table 3과 같이 도출할 수 있다.

또한, 차량화재시 발생되는 열방출율은 화재강도와 비례되 며, 화재규모 산정에 있어서 중요요소이다. 발열량은 질량에
따라 많은 차이가 나타나며, 차량의 경우 구성재료·재질에 따 라 발열량이 다르기 때문에 국내 차량에 대한 발열량 Data확 보가 필요하다.

특히, 차량 구성품의 내 · 외장재 연소물의 중량과 연소열을 도출하면 차량 종류에 관계 없이 총 발열량을 추산할 수 있다. 연소열은 연소물량과 총 발열량을 통해 다음 식 (4)와 같이 계산이 가능하며, 다음 Table 4 와 같이 도출할 수 있다.

$$
H c=\frac{T H R}{C}
$$

$H c$ : Heat of Combustion $[\mathrm{MJ} / \mathrm{kg}]$

THR: Total Heat Release [MJ]

$C$ : Combustibles $[\mathrm{kg}]$

본 연구에서는 실물 차량에 대한 연소실험에 대하여 기초적 인 실험을 실시하였으며, 이를 통해 국내 차량 종류에 따른 기초적인 Data를 확보할 수 있었다. 그러나, 국내 계측장비의 실정에 따라 차량의 연료, 타이어의 공기압을 제거하였기 때 문에 실제 차량화재시 더욱 위험성이 높다고 판단된다. 또한 지하 주차공간의 경우 환기인자로 인해 화재성상이 변화될 것으로 판단되며 이를 고려한 향후 연구가 필요하다고 사료 된다.

\section{4. 차량화재의 열방출율 모델화 및 DB구축}

\section{1 열방출율의 모델화}

일반 건축물화재는 내화설계(AIJ 2005)를 위해 다음 Fig. 15 와 같이 4 개의 구간으로 구분하여 모델화가 가능하다고 제 시하였다.

1 단계 : 훈소기간 $\left(\tau_{0}\right)$ : 발화 후, 연소가 성장하기 시작할 때 까지의 훈소상태의 기간 $\left(0 \sim t_{0}\right)$.

\begin{tabular}{|c|c|c|c|c|c|c|}
\hline \multirow{2}{*}{ Specimens } & Initial mass & Post mass loss & Mass loss & Fire duration & Combustion ratio & Burning rate \\
\hline & {$[\mathrm{kg}]$} & {$[\mathrm{kg}]$} & {$[\mathrm{kg}]$} & [min] & [\%] & {$[\mathrm{kg} / \mathrm{min}]$} \\
\hline Mid-size car & 1,254 & 1,095 & 159 & 35 & 12.7 & 4.54 \\
\hline Large-size car & 1,760 & 1,470 & 290 & 47 & 16.5 & 6.17 \\
\hline Van & 1,916 & 1,610 & 306 & 37 & 16 & 8.27 \\
\hline
\end{tabular}

2 단계 : 성장기간 $\left(\tau_{\text {grow }}\right)$ : 연소가 성장하기 시작해 최대 연소

Table 3. Properties of Vehicle Cumbustion

Table 4. The results of THR and Heat of Combustion

\begin{tabular}{c|c|c|c|c}
\hline Specimens & $\begin{array}{c}\text { Maximum heat release rate } \\
{[\mathrm{MW}]}\end{array}$ & $\begin{array}{c}\text { Total heat release } \\
{[\mathrm{MJ}]}\end{array}$ & $\begin{array}{c}\text { Combustibles } \\
{[\mathrm{kg}]}\end{array}$ & $\begin{array}{c}\text { Heat of combustion } \\
{[\mathrm{MJ} / \mathrm{kg}]}\end{array}$ \\
\hline Mid-size car & 3.6 & 5,253 & 159 & 33.0 \\
\hline Large-size car & 3.6 & 4,789 & 290 & 16.5 \\
\hline Van & 4.3 & 5,860 & 306 & 19.2 \\
\hline
\end{tabular}






Fig. 15. Modeling of Heat Release Rate.

에 도달할 때까지의 기간 $\left(t_{0} \sim t_{\text {grow }}\right)$.

3 단계 : 정상 기간 $\left(\tau_{\max }\right)$ : 최대 발열 속도 상태로 정상 연소 하는 기간 $\left(t_{\text {grow }} \sim t_{\max }\right)$.

4 단계 : 감쇠 기간 $\left(\tau_{\text {decay }}\right)$ : 연소가 감쇠하기 시작하고 화염이 소멸 될 때까지의 기간 $\left(t_{\max } \sim t_{\text {decay }}\right)$.

또한 모델화된 발열량에서 화재성장율(Fire growth rate) $\alpha$ 식 (5)과 같이 도출할 수 있으며, 화재가 감쇠하는 기간에서의 감쇠율은 $\alpha d$ (최대 발열량으로부터 화염이 소멸될 때까지의 2 차 곡선) 식 (6)과 같이 도출할 수 있다.

$$
\begin{aligned}
& \alpha=Q_{\text {max }} /\left(t_{\text {grow }}-t_{0}\right)=Q_{\text {max }} / \tau_{\text {grow }}^{2} \\
& \alpha_{d}=Q_{\text {max }} /\left(t_{\text {decay }}-t_{\max }\right)=Q_{\max } / \tau_{\text {decay }}
\end{aligned}
$$

\section{2 차량연소 실험결과를 이용한 열방출율의 모델화}

전술한 차량연소특성 결과와 열방출율의 모델화를 이용하 여 다음 Figs. 16 18과 같이 나타내었다. 차량연소실험의 DB 구축과 식 (5)를 이용하여 각 차량의 최성기까지 도달하기 전의

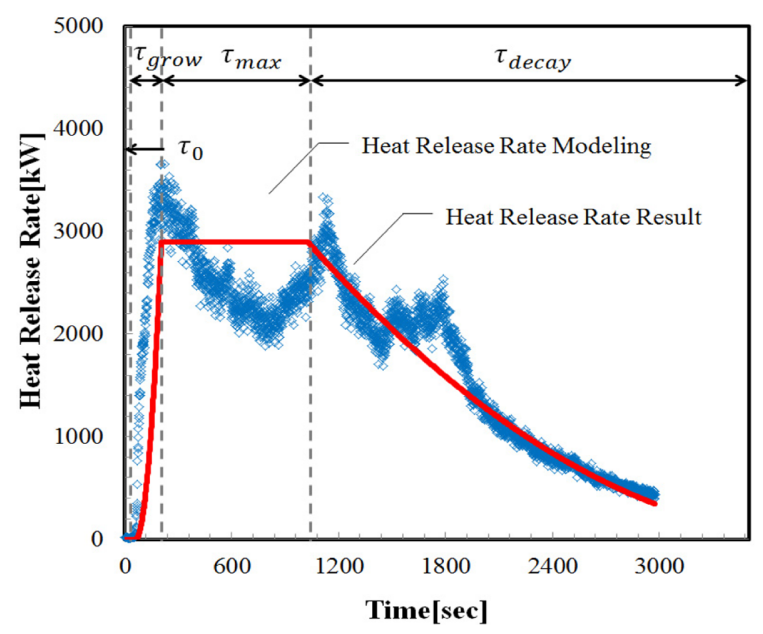

Fig. 16. Modeling (Mid-size Car).
화재성장율을 도출한 것을 다음 Table 5에 나타내었다. 또한 차량화재의 열방출율 모델화는 실험값과 모델값의 총 발열량 을 계산하여 열방출율 면적의 오차값이 $10 \%$ 내 범위에 있도 록 설정하였다.

각 차량에서 도출된 화재성장율을 비교하면 중형승용차, 대 형승용차, 승합차 순으로 나타났으며, 주차공간의 화재안전설 계를 위한 국내 차량 종류별 기초 $\mathrm{DB}$ 를 제시하고자 한다.

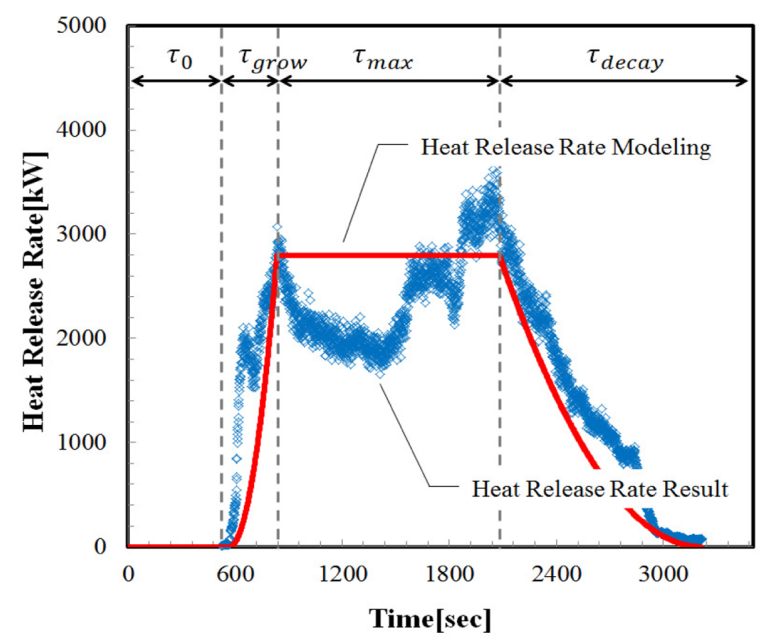

Fig. 17. Modeling (Large-size Car).

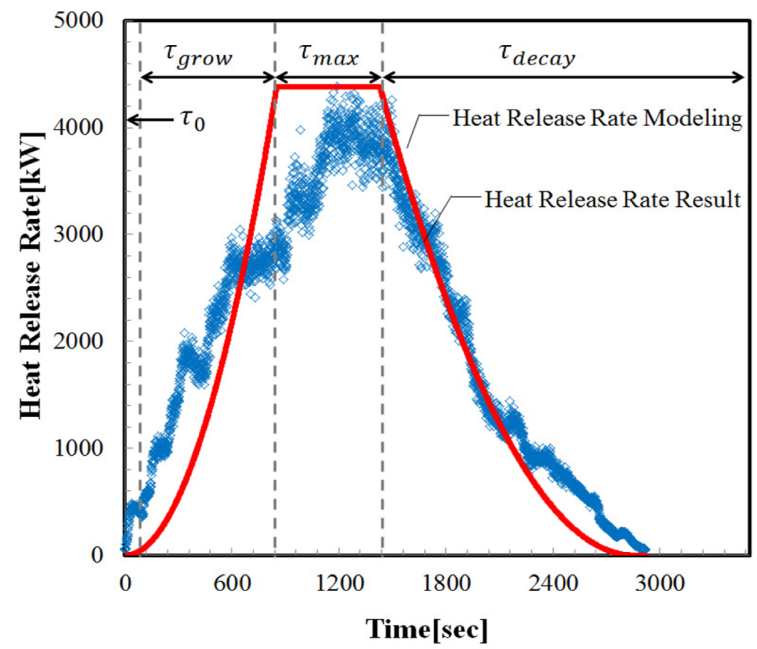

Fig. 18. Modeling (Van).

Table 5. Data Base for Vehicle Modeling the HRR

\begin{tabular}{c|c|c|c}
\hline & Mid-size car & Large-size car & Van \\
\hline$\tau_{0}[\mathrm{~s}]$ & 60 & 568 & 10 \\
\hline$\tau_{\text {grow }}[\mathrm{s}]$ & 146 & 835 & 1191 \\
\hline$\tau_{\max }[\mathrm{s}]$ & 820 & 2080 & 1495 \\
\hline$\tau_{\text {decay }}[\mathrm{s}]$ & 2975 & 3214 & 2919 \\
\hline$Q_{\max }[\mathrm{kW}]$ & 2900 & 3200 & 4379 \\
\hline$T H R[\mathrm{MJ}]$ & 5,277 & 4,793 & 5,859 \\
\hline$\alpha\left[\mathrm{kW} / \mathrm{sec}^{2}\right]$ & 0.153453 & 0.004589 & 0.003087 \\
\hline
\end{tabular}




\section{5. 결 론}

주차공간의 차량종류별 연소특성의 $\mathrm{DB}$ 구축과 기초적 설계 용 모델화를 위해 본 연구는 중형승용차, 대형승용차, 승합차 차량 종류별 3대를 선정하여 Large Scale Calorimeter 연소실 험을 실시한 결과 다음과 같은 결과를 얻었다.

1) 중형승용차, 대형승용차, 승합차의 온도특성결과, 내 - 외 부 최고온도 $1036.6^{\circ} \mathrm{C}, 1137.7^{\circ} \mathrm{C}, 1064^{\circ} \mathrm{C}$ 가 측정되었으 며, $2.3 \mathrm{~m}$ 위치에서의 최고온도는 대형승용차에서 $642^{\circ} \mathrm{C}$, 승합차에서 $428^{\circ} \mathrm{C}$ 가 측정되었으며, 국내 건축물에 적용 되고 있는 ISO 834 곡선보다 높은 온도가 측정되어 주차 공간 구조물의 내화성능 검토가 필요할 것으로 사료된다.

2) 최고 열방출율은 각각 $3.6 \mathrm{MW}, 3.6 \mathrm{MW}, 4.3 \mathrm{MW}$ 와 총 발열량 $5,253 \mathrm{MJ}, 4,789 \mathrm{MJ}, 5,860 \mathrm{MJ}$ 로 나타났으며, 차 량의 구성재료에 따라 총 발열량이 결정되는 것을 알 수 있었다. 또한, 차량의 연소전 · 후의 중량과 화재지속시간 을 통해 중형승용차, 대형승용차 승합차의 연소속도 $4.54 \mathrm{~kg} / \mathrm{min}, 6.17 \mathrm{~kg} / \mathrm{min}, 8.27 \mathrm{~kg} / \mathrm{min}$, 연소물비율 $12.7 \%$, $16.5 \%, 16 \%$, 연소열 $33.0 \mathrm{MJ} / \mathrm{kg}, 16.5 \mathrm{MJ} / \mathrm{kg}, 19.2 \mathrm{MJ} /$ $\mathrm{kg}$ 을 도출하였고, 차량의 열방출율을 이용하여 차량별 화재성장율을 도출한 결과, 중형승용차, 대형승용차, 승 합차의 순서로 화재성상이 빠르다는 것을 확인 할 수 있 었다.

3) 차량연소에 대한 기초적인 결과 Data를 이용하여 훈소기 간 $\left(\tau_{0}\right)$,성장기간 $\left(\tau_{\text {grow }}\right)$,정상기간 $\left(\tau_{\max }\right)$,감쇠 기간 $\left(\tau_{\text {decay }}\right)$ 의 4 구간의 열방출율 모델화를 수행한 결과 차량별 모델 값 의 총 발열량은 실험값과 오차 범위가 $10 \%$ 내에 있도록 설정하였으며 주차공간 구조물의 내화설계를 위한 기초 적 $\mathrm{DB}$ 구축을 위한 자료로 제시하였다.

본 연구에서는 차량연소에 대한 기초적인 Data 확보를 위 해 차량연소실험을 실시하였다. 하지만, 국내 계측장비의 실 정에 의해 차량의 연료와 타이어의 공기압을 제거하여 실제 차량 화재시 더욱 위험성이 높다고 사료된다. 향후, 국내 차량 의 구성재료 - 재질에 대한 기초적인 발열량 $\mathrm{DB}$ 확보가 필요 하며, 주차공간 특성과 환기인자를 고려한 주차공간의 화재안 전설계가 이루어지는 것이 필요하다고 사료된다.

\section{감사의 글}

본 연구는 이 연구는 2011년도 건설교통기술연구개발사업 11 첨단도시 C01지원에 의한 것으로, 관계자께 감사드립니다.

\section{References}

Architectural Institute of Japan (AIJ) Fire-resistant design WG Team, (2005) "A part fire is supposed For Fire-resistant design", Architectural Institute of Japan, Japan.

Kim, D.E. Seo, D.G., and Kwon, Y.J. (2013) "A Study on the Combustible Materials DATA BASE of a Residential Facilities", Korean Society of Hazard Mitigation, Vol. 13, No. 3, pp. 23-28.

Kim, D.J. (2013) "Structural Behavior and Heat Conduction Analysis on the RC Slab of Performance Based Fire Resistance Design for Parking Space in High Rise Building", Hoseo Univ. Doctor's thesis.

Kim, Y.T. (2010) "A study on the Combustion of Car Interior Materials", Kangwon Univ. Master's thesis

Mangs, J. (1994) "Characterization of the fire behavior of a burning passenger car Fire Safety Journal, Vol.23, No.1, pp. 37-49.

Masuda, H. (2005) "A Study on Fire Properties and Conutermeasures for Spaces Exposed to Vehicle Fire", Chiba Univ. Doctor's thesis.

Shipp, M. and Michael, S. (1995) "Measurement of the severity of fire involving moter vehicle fire and material", Fire and Materials, Vol. 19, Issue. 3

Statistics Korea, Vehicle Registration Status (2012)

The Korea Transport Institute, Parking a lot Places (2012)

Yoo, Y.H. Kim, H.Y. Shin, H.J., and Ryu, S.H. (2007) "Development and of large cone calorimeter for the real scale fire test", Korean Institute of Fire Science \& Engineering, Proceedings of Spring Annual Conference, pp. 18-23.

Yoo, Y.H. Kwon, O.S., and Kim, H.Y. (2010) "An Experimental Study for Fire Spread of Compact Cars", Korean Institute of Fire Science \& Engineering, Proceedings of Spring Annual Conference, pp. 279-283.

\begin{tabular}{|l|l|}
\hline Received & December 12, 2013 \\
\hline Revised & December 16, 2013 \\
\hline Accepted & December 30, 2013 \\
\hline
\end{tabular}

